\title{
NIETZSCHE'S UBERMENSCH AND CRIME: AN ANALYSIS OF ARVIND ADIGA'S NOVEL THE WHITE TIGER
}

\author{
Gohar Ayaz* \& Dr. Snobra Rizwan ${ }^{\dagger}$
}

\begin{abstract}
This paper analyzes the act of crime and its artistic rationalization through the character of Balram Halwai in ArvindAdiga's novel The White Tiger under the theoretical prism of Nietzsche's Philosophy of Ubermensch. Ubermensch is a hypothetical character proposed by Nietzsche in his masterpiece Thus Spoke Zarathustra, who is expected to appear in the future and will possess some unique features like 'transcendence over society', 'creation of new values and master morality', 'will to power and achievement'. The character of Balram is analyzed as a fictional Ubermensch under the lens of these features using Content Analysis Technique of Qualitative Research Methodology', which is considered suitable for the specific descriptive nature and scope of this study. This analysis concludes that the embodiment of such features by Balram justifies his rise as a perfect potential Ubermensch of $21^{\text {st }}$ century, who rejects the traditional moral system and builds his own system of morality where crime also seems to be rationalized.
\end{abstract}

Keywords: Balram, crime, Mr. Ashok, murder, Nietzsche, Ubermensch, white tiger

\section{Introduction}

Human beings are born with a natural tendency to achieve a higher status in the society for which they struggle in their lives. Every individual desires to be counted among great men either by earning money and fame or

\footnotetext{
* HEC PhD Scholar, Institute of Social Sciences, BZ University, Multan. Email:goharayaz.phd@gmail.com

+ Assistant Professor, Department of English, BZ University, Multan. Email:snobrarizwan@hotmail.com
} 
gaining political or social power. It is a fact that "great men are not born great, they grow great" (Puzo, 1969, p. 180). Although it seems a positive attitude yet in some cases this tendency surpasses its limits and turns into a monstrous evil. Such kind of tendency leads a human being to materialistic success in life but on the another hand it also lands him to the world of crime as it is a widely-known fact that "behind every great fortune there is a crime" (Puzo, 1969, p. 1). Merriam-Webster defines crime as an unlawful deed for which an individual may face a penalty from the Government. It can also be defined as an act where duties and public rights are violated (Blackstone, 1765). Yet there is another elaborated description of crime which says that it is a damaging and immoral act and is considered an evil by the community as it violates the moral values of a society (Garofalo, 1914 , p. 59). A crime is also referred to as an act that is either dangerous to the community in real or is considered so by some individuals who have the authority to impose penalty on such acts and persuade others to accept their decisions (Gillan, 1945, p. 9). Therefore, a crime is something that is neither appreciated by society nor by any law of a state. The same is true about a criminal, who is treated as a socially deviant and exceptional because of his acts which are repugnant to the conventional moral system of that society.

Literature is full of such characters who are projected as criminals in one way or another but in most of the cases they are given the due punishment owing to poetic justice either by natural justice or by some machinery of the community or government. There are rare cases in fictions, where criminals are shown walking freely in the society. One of such characters is Balram Halwai in the Man Booker Prize winning novel The White Tiger written by Arvind Adiga. He commits a crime of killing his own master Mr. Ashok and bribing the police but is never caught throughout the novel. He risks the lives of his whole family and justifies all his heinous acts in a unique way. He is a kind of character, who would not bother to breach any moral or legal law on his way to become a successful businessman. This deviation of a criminal from the norms and values of a community leads us to pass such character through the prism of Nietzsche's philosophy of Ubermensch.

As described in Thus Spoke Zarathustra, Nietzsche prophesizes about the arrival of an extraordinary individual whom he calls an Ubermensch. It is a term used in German language, which may be translated as 'overman' or 'superman' but in order to keep its real sense intact the original term is used in this research. As per the philosophy of Nietzsche, such an individual will rise one day in the future. Ubermensch is an individual, who struggles to the best of his capacity to gain a higher position in the society and live beyond the life of an ordinary human being. For this purpose, he must reject and violate the established moral laws of his community and the state in which he lives. In case of such deviation he establishes his own moral system in which he acts and justifies his actions on his self-developed standards as a result of which the lives of other individuals are affected. Ubermensch is a 
surprising character having exceptional characteristics and insightful thoughts. His extraordinary character has the capacity to convince and lead other individuals to the new world, where his own established innovative moral system prevails. According to Nietzsche, he will be a role model for humanity, and will be the beginning of new life as he elaborates it in the following words.

I teach you the over man, man is something that shall be overcome. What have you done to overcome him? All beings so far have created something beyond themselves, and do you want to be the ebb of this great flood and even go back to the beasts rather than overcome man? What is the ape toman? A laughing stock or a painful embarrassment. And man shall be just that for the over man: A laughing stock or a painful embarrassment... Behold, I teach you the Over man. The over man is the meaning of the earth (Nietzsche, 2010, p. 6)

\section{Literature Review}

The character of Balram and his behavior is the most commented idea so far dealt in research done on Adiga's novel The White Tiger. The current study is also related to a new aspect of Balram's character. However, the previous relevant literature available on this character is dealt with in this section. Beginning with Maji (2015), who argues that Balram decides to take the path of rebellion against all the social, religious and state institution in order to win a free life from the coop (p. 351). Such a rebellious act on his part raises him to the status of an Ubermensch. Mondal (2015) states that the only option left with Balram was to cheat on his masters and kill Mr. Ashok as a result of which he may live a prosperous life. He gives practical shape to his intentions and flees to Bangalore, where he starts his own business. Readers do not witness Balram's regret over his act of crime at any stage in the novel. He even justifies it by declaring that it was due to his desperation (p. 14). Such an absurd explanation is not acceptable in traditional society, which suggests that he must be taken as an extraordinary being like an Ubermensch. Jadhav (2014) sympathizes with Balram and defends him as a man, who suffered a lot in his life that is why he opted to live with a crime not to die like his father who died while waiting for a physician in the hospital (p. 38). He did not want to leave this world having no individual identity but to escape that cage and live like a white tiger (p. 40). Balram is in dire need of success for which, he goes to an extreme of committing a heinous crime. He actually wants an absolute freedom from the bonds of societal and religious morality which makes him a true Ubermensch of the modern day. Sebastian (2009), while contrasting the characters of Balram and his master Mr. Ashok, identifies Balram as a true hero of Indian society who does not bother to kill someone in order to clear his way of success (p. 230). According to Choudhury (2014) Balram is an 
extremely ambitious and innovative person, who turns his dreams into reality and moves upward in his social status. He made huge sacrifices for his achievements and accomplishments (p. 153). Singh (2009) suggests that the indulgence of Balram in various evil activities are the result of his frustration against the rich people around him (p. 98). The novel is a clear justification of Balram's criminal acts in which he is appreciated as a determined person who raises from Munna to Ashok Sharma (p. 102). Balram is emerged as a halfbacked man who turns out to be an extraordinary character in the lines of Nietzsche's Ubermensch. Priyanka (2015) declares Balram as an overman or an extraordinary man in her comparative analysis of Raskolnikov and Balram (p. 157). Balram does not think and act like commoners that is why he transcends them and reaches at the apex of social strata (p. 162). Balram is widely discussed in these articles on the grounds of his distinctive features, which are also seem to be present in the proposed Ubermensch of Nietzsche. Ubermensch is a kind of rebellious character like Balram who does not care about religious or social constraints. As Nietzsche (1974) asserts:

The superman is precisely the one who knows that God is dead and that religion no longer control us. He knows that his kind needs no God for meaning that one can comfortably live in ameaningless universe because one organizes a portion of it for oneself (p. 585)

\section{Methodology, Research Technique and Theoretical Framework}

This study has adopted 'Content Analysis Technique of Qualitative Research Methodology', which is considered suitable for the specific descriptive nature and scope of this study. In case of purely descriptive study content analysis is highly recommended in qualitative research methods (Kumar, 2011). Similarly, Cohen (2018) recommends the use of content analysis to summarize and report main contents of any written information. Moreover, content analysis method augments researchers to systematically analyze textual information contained in books, newspapers etc. (Sekaran and Bougie, 2016). Descriptive method has the capacity to accommodate qualitative method, which is applied in this paper so that the application of Nietzsche's Philosophy of Ubermensch is qualitatively analyzed in the selected novel. In order to gain a deep rooted insight into this study, Content based qualitative analysis technique is applied, where content of the novel is considered for interpretation of the features. These features are common in both Nietzsche's proposed Ubermensch and the target character of the novel that is Balram. Instead of focusing the text, content is analyzed qualitatively to arrive at results of the proposed idea.

Nietzsche animates the idea of Ubermensch in his novel Thus Spoke Zarathustra through the character of Zarathustra and then elaborates it in his other works. All the possible features of Ubermensch gathered from his novel and other works leads the researcher to build the theoretical framework of this 
research. Copleston (1963) suggests that Nietzsche's Ubermensch will break the old table of values and create his own moral system using his power and wit (p. 415). The same way Hill (2007) argues that the summarized words of Zarathustra suggest that Ubermensch is an individual having will to power with symbolic representation of affirmation, regeneration and integration having the ability to construct his own morality (p. 124). Mercier (2002) opines that Ubermensch is an individual who will assert his power and will be hated by others but he will turn deaf and blind over it and will continue his struggle to achieve something in his life at the cost of everything (p. 93). Such a brief background of Nietzsche's Ubermensch builds the theory of Ubermensch highlighting his salient features like will to power, rejection of old values, constructing new morality, affirmation and achievement. This theory is applied to Balram Halwai, the protagonist of Adiga' novel The White Tiger. Hence, the theoretical framework for this study also embodies the same theory of Ubermensch. All the basic features of Ubermensch as described by Nietzsche like rejection of all religious and social values, creating own space and following own master morality are being scrutinized in the character of Balram Halwai. Balram's justification of committing a crime is being rationalized by placing him under the light of Nietzsche's philosophy of Ubermensch.

\section{Analysis and Discussion}

The White Tiger by Arvind Adiga is written in the form of a lengthy letter by a successful businessman of Bangalore named Balram Halwai to the PM of China Mr. Jiabao, who is expected to pay a state visit to India in the near future. This novel describes the story of Balram who was a poor fellow of Laxmangarh and a son of an auto driver. The novel is a bildungsroman of his transformation from a poor child and an uneducated chauffeur to successful and famous businessman of Bangalore. Balram is depicted as an exceptional individual, who is in search of some real freedom from the social bonds and his efforts to rise above the world of poverty and darkness. Briefly, this novel is a chronological investigation into the journey of Balram from the world of darkness to that of lightness. Balram belongs to the world of darkness and through the letters written in seven nights he has successfully and artistically revealed the disgusting truths about life in India. He elaborates all the struggles and sufferings he has faced in his life because of his low social status projecting the prevailing social evils including exploitation, class or caste differences, poverty and corruption. This whole transformation journey of Balram from a young boy of a village to the prosperous businessman of Bangalore is tremendously interesting. During this transformation, he turns into a criminal by killing his own master and becomes one of those whom he previously considered corrupt. Balram is an ambitious man and in order to sustain his individual identity, high rank and prosperous life in the society, he 
kills Mr. Ashok with whom he used to be a chauffeur. To have an insight into the criminal character of Balram, the researcher is going to look at him from the beginning till end using the features of Ubermensch such as individuality, extraordinary ideas, rejecting conventional morality, creator of new values, creator of master morality and achievement.

At the very outset of the novel, while addressing the PM of China in his letter, Balram ranks himself among great people of the contemporary world. It is evident from his statement, where he claims that he has no grievances against great men because he considers himself as one of such kind (Adiga, 2008 , p. 3). He again claims to be a superior human being as he declares himself "a man of change and action" (p. 5). Once more he reveals his superiority by declaring himself as a man who does not dwell in past or present but lives for tomorrow or future (p. 6). In order to justify his claims, he narrates a story of his intellectual ability and uniqueness. When a school Inspector visits his school so that their knowledge may be tested, Balram imprints a good impression on him by answering all the questions correctly. The Inspector appreciates the honesty, sharpness and intelligence of Balram and titles him as a white tiger among other students who are referred to as idiots and thugs (p. 35). Such an introduction of the protagonist paves way for his development as an extraordinary being like an Ubermensch of Nietzsche. Since, Balram embodies the features of individual identity and extraordinary character he may be termed as a potential Ubermensch of $21^{\text {st }}$ century fiction.

Turning to the ideology and philosophy of Balram behind his criminal act which is crucial for this paper, he considers his master Mr. Ashok as corrupt man who has no right to exist in this world. According to his belief the only use of Mr. Ashok is to be killed and to be deprived of his wealth. Balram is of the opinion that it is not possible for him or anyone to become successful in the contemporary dark society full of corruption until he joins this corrupt and criminal world. He often shows signs of resentment over the plight of those poor fellows of his society, who are unable to break the chains of poverty and slavery and rise to a higher status. He rebukes them for being poor from birth till death. He calls them servants forever, who are unable to cast off the stigma of slavery from their instinct (p. 298). He consider such people as weak and pathetic who do not even struggle in their own capacity to escape such miserable life and excel their standard of life. As per Balram's ideology such people do not possess the strength of will power and their cowardice restricts them from showing courage. On the other hand he thinks that he stands at a higher position as compared to others of the same class or creed because of his strength of will power like a potential Ubermensch and his ability to escape the cage of roosters. He declares his success to escape this coop and yells proudly that he has made it and broken out of the coop (p. 320) by achieving high status in the society and becoming a self-made man. He further celebrates his victory by declaring that he was once a driver of a master and currently he is master of drivers (p. 302). Once again the features of will power, courage 
and achievement are prominent in his character like an Ubermensch, which are also the pillars for his crime and its justification.

Balram straightway rejects the moral system of his society and constructs his own morality, where committing the crime of killing $\mathrm{Mr}$. Ashok is the only source to achieve his aim and fulfil his desire of becoming a rich man. His actual desire is to pursue upward social mobility in which he moves from the world of darkness to that of light. He himself turns into one of Mr. Ashok kind of persons after killing him, but he achieves a distinctive identity of a new nature. He declares that he calls himself as Ashok Sharma after killing him but with a new identity as Ashok Sharma, who is settled in Bangalore and is a North Indian Entrepreneur (p. 302). Therefore, Balram believes that if he wants to escape the cage of roosters and secure a high rank in the dark society he must kill Mr. Ashok first. Only this way he may become the owner of a new world where darkness will fade away. Consequently, Balram is projected as a murderer and an immoral character who even dares to justify his crime of killing his master under the rules made under his own moral system.

Balram is a free soul having individual thoughts, who does not rely on moral laws of his society and chooses his life preferences out of his own free will. In the first place, he violates the decisions of his family about his future. They wanted to engage him in the business of confectionary but he flees to Delhi and becomes a chauffeur there. He is following the footsteps of an Ubermensch as he embodies the strength of free will and seeks freedom from the bonds of society and religion along with absolute independence in his life. He deliberately reveals the hypocritical nature and evil face of Indian society which is strangled by vices including class and caste discrimination, corruption, dowry and poverty. Balram is actually the mouthpiece of the underprivileged class and embodies their frustration, revenge, anger and protest in his character. He is always prepared to reject the traditional moral system and embrace any new moral code in order to find freedom and success in his life (Chopra, 2011). For the purpose of reaching at the apex of social hierarchy, Balram chooses to commit a crime of killing Mr. Ashok. As a justification of his crime he argues that the history is full of such examples where powerful individuals are often found with blood on their hands. They do not hesitate to kill someone just to reach the target they have set for themselves. He claims that all such great and powerful men including the prime minister of India are involved in the crime of murdering someone. The government and the people will place bronze statues of criminals in front of Parliament in Delhi (Adiga, 2008, p. 318). He strengthens his claim by arguing that such kind of criminals are appreciated in this country instead of rebuking them. Balram, while rationalizing his immoral criminal act, maintains that he was actually in search of chance to become a powerful man and his crime of murdering his master was enough for this (p. 318). He seems extremely arrogant in his views about himself as 
he considers that he has the ability and capacity like Nietzsche's Ubermensch to eliminate the evils from the society and change it completely. He claims that individuals like him are the only hope of humanity to break the rooster coop and free all of them from the chains of moral values and norms of the society, state and religion (p. 320).

It is crucial to note in the character of Balram that he is consistent in his motive and ideas and the crime he committed does not affect his thoughts. He does not act like a common man who feels guilty after committing such a crime and feel fear of loneliness in such situations. His steadfast character resembles that of consistent Ubermensch who is an indifferent individual when it comes to the lives of others. Absence of any fear or guilt in Balram suggests that he is ambitious and wants to be a successful and rich person in his society. As Balram does not roam in past or dwell in present but looks forward for a bright future that is why he is not easily caught by guilt or falls into hopelessness. Such an attitude is evident from his claim about his own character, where he says that he is kind of an individual who looks for tomorrow, while other people see today (p. 319). In order to step into his tomorrow of brightness, Balram kills his master and declares it his first step to accomplish his plans and achieve his aim. Balram proves that he is the real creator of new moral system like an Ubermensch as he points out; "It may turn out to be a decent city, where humans can live like humans and animals can live like animals. A new Bangalore for a new India. And then I can saythat, in my own way, I helped to make new Bangalore" (pp. 317318). Bangalore may be taken a symbolic representation of the new morality system created by Balram where he observes his own values and norms. He is confident about his success in eliminating the evils of the society and changing it by giving a new moral code of his own.

Soon after killing Mr. Ashok in Delhi, he escapes successfully escapes and reaches Bangalore, where he flourishes his own Taxi services business and becomes a successful and renowned businessman. Not a single instance is found in the whole novel where he feels guilty or regrets over the murder of his master rather he is happy to experience the feelings after escaping the life of a servant (p. 321). He also justifies his crime by arguing that those powerful and rich men need to be punished who exploit the poor ones. He does not care about his family, even when he decides to kill Mr. Ashok and steals his wealth because the father and other family members of Mr. Ashok will obviously go for revenge. He becomes a true Ubermensch and rationalizes his act of killing by declaring himself an extraordinary man who dares to escape the coop of roosters at the cost of his family members who are expected to be beaten, hunted and destroyed by the family members of Mr. Ashok (p. 176).

All the above facts bring Balram under the merit of Ubermensch as he fights alone having strong will to power and does not get influenced by the will of other people. Such affirmation of will power makes a person stranger 
or outsider in his own society. Balram succeeds absolutely in claiming his freedom of will to power without any hindrance built by the traditional values and norms of his society. The character of Balram embodies the required strength of will power to take absolute control over his desires to influence others. Balram is a kind of extraordinary human being who has the guts to kill his master and endanger his family but never sets back from becoming a successful and prosperous business man in the society ignoring any fear of being punished or bearing any feelings of guilt. He symbolizes a true and potential Ubermensch who pleases his desires at the cost of his will power.

Literature is full of such characters who are created by novelists after being inspired from the Ubermensch Philosophy of Nietzsche. All such characters are not complete representations of Nietzsche's Ubermensch as they lack one or two features but Arvind Adiga's Balram is the most recent development form of a fictional Ubermensch. All the thoughts and actions of Balram resemble those of Nietzsche's Ubermensch, which justifies criminal character of Balram in The White Tiger. The proposed Ubermensch of Nietzsche is an extraordinary individual who rejects the conventional moral system of the society which is termed as 'herd morality' or 'slave morality' by Nietzsche. He then creates his own new system of moral values which is termed as 'master morality'. After escaping the chains of societal or religious moral values, the Ubermensch struggles to raise the standards of humanity by convincing others to follow his ideals in order to succeed in life. He then turns into a role model for other individuals, who are interested in a free life. Balram is referred to as a rare white tiger in the novel, which suggests that he is the one who has the will power to leave the world of darkness and enter that of lightness. Such intentions are then proved in his actions which leads the researchers to declare him a true potential fictional Ubermensch of $21^{\text {st }}$ century as Nietzsche had prophesized about its appearance in $21^{\text {st }}$ century.

\section{Conclusion}

The plight of Balram before committing the crime suggests that people like him must think and act to rise in their lives and achieve a higher rank in the society. They must keep an optimistic attitude towards life and possess life affirming approach like Ubermensch but should remain to the limits of their own circles of moral values without crossing the borders of others. Such actions should be restricted, which may result in heinous crimes like Balram did in the novel. Every such individual who wants to follow the footprints of Nietzsche's Ubermensch may opt for such actions which are constructive for the humanity and helpful in bringing a positive spirit of living in the society. Indulgence in criminal acts may result in one's own success but it may prove fatal for the lives of others resulting chaos in the society.

\section{References}


Adiga, A. (2008). The White Tiger. India: Harper Collins Publishers.

Blackstone, W. (1765). Commentaries on the Laws of England. Oxford: Oxford University Press

Chopra, R. (2011). Social Criticism in AravindAdiga'sThe White Tiger, Literaria: An International Journal of New Literature across the World, 1(2), pp. 30-39.

Choudhury, A.M. (2014). Aravind Adiga's The White Tiger as a Reinscription of Modern India. IJLL, 2(3), pp. 149-160.

Cohen, L., Manion, L., and Morrison, K., (2018). Research Methods in Education. New York: Routledge.

Copleston, F. (1963). A History of Philosophy. Fichte to Nietzsche. Kent: Burns and Oates.

Garofalo, B.R. (1914). Criminology. Boston: Little, Brown and Company.

Gillin, J.L. (1945). Criminology and Penology. New York: D. AppletonCentury Co.

Hill, K.R. (2007). Nietzsche:A Guide for the Perplexed. London: Continuum International Publishing Group.

Jadhav, P. (2014). Arvind Adiga's The White Tiger: A search for identity. New Man IJMS, 1(4), pp. 36-41.

Kumar, R. (2011). Research Methodology: A step-by-step guide for beginners. New Delhi: Sage Publications India Pvt Ltd.

Maji, S. (2015). The Subaltern Can Speak: A Study of ArvindAdiga'sThe White Tiger. IJAR, 1(8), pp. 351-352.

Mercier, J.L. (2002). From Socrates to Wittgenstein. India: Asian Trading Corporation.

Mondal, P. (2015). The Tradition and Modernity of/in India are at loggerheads: Reading Arvind Adiga's The White Tiger, JSE, 2(1), pp. 1423.

Nietzsche, F. (2010). Thus Spoke Zarathustra. Thomas, C. (Trans.) and William, A C. (Ed.). Feedbooks.

Nietzsche, F. (1974). The Gay Science, NewYork: Vintage Books.

Priyanka, P. (2015). Nietzsche's ubermensch in Fyodor Dostoevsky's Crime and Punishment and Arvind Adiga's The White Tiger. RJELAL, 3(4), pp. 157-162.

Puzo, M. (1969). The Godfather. New York: G. P. Putnam's Sons.

Sebastian, A.J. (2009). Poor-Rich divide in Arvind Adiga's The White Tiger. JAPSS, 1(2), pp. 229-245.

Sekaran, U., \& Bougie, B., (2016). Research methods for business, Chichester, West Sussex, UK: John Wiley \& Sons Ltd.

Singh, K. (2009). Aravind Adiga's The White Tiger: The Voice of Underclass-A Postcolonial Dialectics. JLCMS, 1(2), pp. 98-112. 